\title{
Protracted inhibition of vascular endothelial growth factor signaling improves survival in metastatic colorectal cancer: A systematic review
}

\author{
Francesco Montagnani, Greta Di Leonardo, Mariasimona Pino, Simona Perboni, \\ Angela Ribecco, Luisa Fioretto \\ Oncology Department, Istituto Tumori Toscano (I.T.T.), Azienda Sanitaria di Firenze, Piazza Santa Maria Nuova 1, \\ Florence 50122, Italy
}

\section{ABSTRACT}

Clinical data suggest that beyond-progression, the blockade of angiogenesis is associated with improved survivals in colorectal cancer. We conducted a systematic review to investigate the therapeutic effects of antiangiogenic drugs administered as later lines of treatment in patients already progressed to a previous anti-VEGF based treatment. An extensive literature search was conducted. Hazard ratios (HR) for progression (PFS) and death (OS) were extracted. An inverse-variance meta-analysis model was implemented. 6 randomized controlled trials were retrieved, including 3407 patients, treated with different antiangiogenic drugs. All of them had progressed during or after a previous line of treatment with bevacizumab. Overall, both PFS $(\mathrm{HR}=0.63, P<0.001)$ and $\mathrm{OS}(\mathrm{HR}=0.81, P<0.001)$ were significantly increased with the use of antiangiogenic drug. No heterogeneity was observed despite different drugs. Protracted inhibition of the VEGF pathway is associated with a significant improvement of both PFS and OS, independently from the antiangiogenic agent used.

Key words: colorectal cancer, angiogenesis, beyond-progression, systematic review

\section{INTRODUCTION}

Angiogenesis is a critical step in colorectal cancer growth, progression and metastasization. The process of blood vessels formation involves many different molecules and pathways. Among these, the vascular endothelial growth factors (VEGFs) driven pathway is one of the most powerful and better studied. ${ }^{[1]}$ VEGFs comprises a family of multiple growth factors that act through the activation of at least three different receptors. ${ }^{[2]}$ In a landmark trial, the anti-VEGF-A monoclonal antibody bevacizumab improved progression-free survival (PFS) and overall survival (OS) when added to IFL chemotherapy for the treatment of metastatic colorectal cancer patients ${ }^{[3]}$ Since then, many studies confirmed the benefit of bevacizumab when added to both first- and second- line chemotherapy. ${ }^{[4,5]}$ More recently, other drugs able to inhibit the VEGFR signaling showed efficacy, like the VEGFtrap Aflibercept, the anti VEGFR-2 Ramucirumab, and the tyrosine kinase receptor inhibitor (TKI) Regorafenib. ${ }^{[-8]}$ There are uncertainties regarding the best duration of an antiangiogenic treatment. Resistance to antiangiogenic agents can develop, mainly through the activation of other pathways like fibroblast growth factor (FGF) and platelet derived growth factor (PDGF). ${ }^{[9]}$ Some authors have argued that, since resistance is established, the sudden suspension of the antiangiogenic drug can rapidly increase blood vessels formation, with more pronounced angiogenesis and faster progression, suggesting possible benefits from longer treatment durations. ${ }^{[10]}$ Recently, two randomized trials investigated the administration of 
bevacizumab beyond progression. ${ }^{[11,12]}$ In these studies, patients progressed after the failure of a bevacizumabbased first line chemotherapy were randomized to continuation or suspension of bevacizumab. The chemotherapy backbone was changed. They both showed that continuation of bevacizumab can effectively improve survival, even if to a small amount. In order to verify if this strategy could be generalized to all the VEGFtargeting drugs, we conducted a systematic review of all the literature available regarding the administration of antiangiogenic drugs targeting VEGF pathway after failure of a previous antiangiogenic therapy and assess if, and to what extent, a survival benefit is present.

\section{METHODS}

PubMED and EMBASE have been searched for randomized controlled trials and meta-analysis using different combinations of the following terms, with no search filter: "metastatic", "colon", "angiogenesis", "colorectal", "vascular endothelial growth factor", "beyond progression"; "Bevacizumab", "Regorafenib", "Aflibercept" and "Ramucirumab". Meta-analysis and previous systematic reviews were also searched using the same combinations with filters for "review", "meta-analysis" or "systematic review". References of the retrieved publications were screened. Abstract and poster presented at the American Society of Clinical Oncology (ASCO) annual meetings, ASCO gastrointestinal symposium, European Society of Medical Oncology (ESMO) annual meetings, and World Gastroenterology Organization (WGO) annual meetings were searched, starting from 2008, using the same combinations as above. We included prospective randomized studies investigating the administration of antiangiogenic drugs targeting the VEGF pathway, either by blocking growth factors or their receptors, irrespectively from their mechanisms of action and administered in patients progressed during or after the treatment with an anti-VEGF drug for metastatic disease. The objective of the analysis was to assess differences in PFS and in OS between patients treated with anti-VEGF therapies versus the untreated controls. PFS was defined as the time since randomization or start of the treatment to clinical evidence of progression, radiological evidence of progression or death, whichever came first. OS was defined as time since randomization or start of the treatment to death from any cause. The retrieved publications were screened by two authors at a title or abstract level. Full publications were obtained for relevant papers. Hazard ratios (HRs) for PFS and OS and their 95\% confidence intervals $(95 \% \mathrm{CI})$ were extracted from the publications. If they were not reported, they were estimated using the Parmar method. ${ }^{[13]}$ The data collection form is given in appendix material. In each randomized study, only the patients previously treated with antiangiogenic agents were included. The risk of bias was evaluated by two different authors using the Cochrane Collaboration's tool. ${ }^{[14]}$ Natural logarithms of the hazard ratios were used as point estimates and standard errors were calculated with the normal approximation. We used inverse variance and random effect model. Between study heterogeneity was tested with Cochran's Q test and I $^{2}$. Sensitivity analyses were performed by repeating the analysis excluding one or more studies each time. If no heterogeneity was found, the analyses were also repeated with fixed effect model. The software used was RevMan v 5.2. PRISMA guidelines were followed to report the results. ${ }^{[15]}$

\section{RESULTS}

Six studies including 3407 patients were included. The trial flow chart is shown in Figure 1. All patients had been previously administered bevacizumab. Except for CORRECT and CONCUR studies, which account for 964 patients, all patients had received only one previous line of treatment. Median age ranged from 55 to 62 years. All the studies carried a low risk of bias for overall survival analysis (Table 2). With respect to progressionfree survival, all studies were scored as low risk, with the exceptions of Bebyp and TML; both were scored as intermediate risk because of the absence of blinding. The analysis for progression free survival showed a significant difference in favor of the anti-VEGF arm with an HR of $0.63(0.60-0.66, P<0.001)$ (Figure 2). Significant heterogeneity was present, and it was mainly attributable to the CORRECT study, in which a greater benefit could be observed. Regorafenib is a TKI that is able to block multiple targets, aside from VEGFRs. We conducted a separate analysis, removing CORRECT and CONCUR, and observed the results (HR $0.71,0.65$ $-0.78, P<0.001)$. Heterogeneity decreased to a nonsignificant level (Cochran $P$ value $\left.=0.12, \mathrm{I}^{2}=48 \%\right)$. The removal of one study at a time also changed the results, and very similar values of HR were obtained (data not shown). The main analysis for OS showed a significant increase in the overall survival $(\mathrm{HR}=0.81,0.76-0.87$, $P<0.001$ ) (Figure 2), with no significant heterogeneity. The exclusion or regorafenib studies or the exclusion of one study at a time did not alter the results $(\mathrm{HR}=0.83$, $0.76-0.89, P<0.001)$. Small study bias and publication bias have been assessed by visual inspection of funnel plot, constructed using the log-transformed HRs for progression free survival Figure 3).

\section{DISCUSSION}

Angiogenesis is a key step for cancer growth and progression. Bevacizumab, an anti-VEGF-A human 
Montagnani et al: : Angiogenesis inhibition in colorectal cancer

\begin{tabular}{|c|c|c|c|c|c|c|c|c|c|c|c|c|c|c|}
\hline \multirow[t]{2}{*}{ Study } & \multirow[t]{2}{*}{ Line } & \multirow[t]{2}{*}{ Treatments } & \multirow[t]{2}{*}{$n$} & \multicolumn{3}{|l|}{ ECOG } & \multicolumn{2}{|l|}{ Sex } & \multicolumn{6}{|c|}{$\mathbf{N}^{\circ}$ of sites of metastases Kras } \\
\hline & & & & 0 & 1 & 2 & $\mathbf{M}$ & $\mathbf{F}$ & $\leq 1$ & $>1$ & n.r. & WT & MT & n.r. \\
\hline \multirow[t]{2}{*}{ TML } & \multirow[t]{2}{*}{$2^{\circ}$} & $\begin{array}{l}\mathrm{CHT}+ \\
\text { Bevacizumab }\end{array}$ & 409 & $\begin{array}{l}179 \\
(43.8)\end{array}$ & $\begin{array}{l}209 \\
(51.2)\end{array}$ & $\begin{array}{l}19 \\
(5)\end{array}$ & $\begin{array}{l}267 \\
(65.3)\end{array}$ & $\begin{array}{l}142 \\
(34.7)\end{array}$ & $\begin{array}{l}148 \\
(36.2)\end{array}$ & $\begin{array}{l}261 \\
(63.8)\end{array}$ & $\begin{array}{l}0 \\
(0)\end{array}$ & $\begin{array}{l}151 \\
(36.9)\end{array}$ & $\begin{array}{l}164 \\
(40.1)\end{array}$ & $\begin{array}{l}94 \\
(23)\end{array}$ \\
\hline & & $\mathrm{CHT}$ & 411 & $\begin{array}{l}178 \\
(43.5)\end{array}$ & $\begin{array}{l}212 \\
(51.8)\end{array}$ & $\begin{array}{l}19 \\
(4.7)\end{array}$ & $\begin{array}{l}259 \\
(62.9)\end{array}$ & $\begin{array}{l}152 \\
(37.1)\end{array}$ & $\begin{array}{l}160 \\
(39)\end{array}$ & $\begin{array}{l}250 \\
(60.8)\end{array}$ & $\begin{array}{l}1 \\
(0.2)\end{array}$ & $\begin{array}{l}165 \\
(40.1)\end{array}$ & $\begin{array}{l}136 \\
(33.1)\end{array}$ & $\begin{array}{l}110 \\
(26.8)\end{array}$ \\
\hline \multirow[t]{2}{*}{ CORRECT } & \multirow{2}{*}{$\geq 3^{\circ}$} & Regorafenib & 505 & $\begin{array}{l}265 \\
(52.5)\end{array}$ & $\begin{array}{l}240 \\
(47.5)\end{array}$ & $\begin{array}{l}0 \\
(0)\end{array}$ & $\begin{array}{l}311 \\
(61.6)\end{array}$ & $\begin{array}{l}194 \\
(38.4)\end{array}$ & n.r. & n.r. & $\begin{array}{l}505 \\
(100)\end{array}$ & $\begin{array}{l}205 \\
(40.6)\end{array}$ & $\begin{array}{l}273 \\
(54)\end{array}$ & $\begin{array}{l}27 \\
(5.4)\end{array}$ \\
\hline & & Placebo & 255 & $\begin{array}{l}146 \\
(57.3)\end{array}$ & $\begin{array}{l}109 \\
(42.7)\end{array}$ & $\begin{array}{l}0 \\
\text { (0) }\end{array}$ & $\begin{array}{l}153 \\
(60)\end{array}$ & $\begin{array}{l}102 \\
(40)\end{array}$ & n.r. & n.r. & $\begin{array}{l}255 \\
(100)\end{array}$ & $\begin{array}{l}94 \\
(36.9)\end{array}$ & $\begin{array}{l}157 \\
(61.5)\end{array}$ & $\begin{array}{l}4 \\
(1.6)\end{array}$ \\
\hline \multirow[t]{2}{*}{ CONCUR } & \multirow[t]{2}{*}{$\geq 3^{\circ}$} & Regorafenib & 136 & $\begin{array}{l}35 \\
(25.7)\end{array}$ & $\begin{array}{l}101 \\
(74.3)\end{array}$ & $\begin{array}{l}0 \\
(0)\end{array}$ & $\begin{array}{l}85 \\
(62.5)\end{array}$ & $\begin{array}{l}51 \\
(37.5)\end{array}$ & $\begin{array}{l}28 \\
(20.6)\end{array}$ & $\begin{array}{l}108 \\
(79.4)\end{array}$ & $\begin{array}{l}0 \\
(0)\end{array}$ & $\begin{array}{l}50 \\
(36.7)\end{array}$ & $\begin{array}{l}46 \\
(33.8)\end{array}$ & $\begin{array}{l}40 \\
(29.5)\end{array}$ \\
\hline & & Placebo & 68 & $\begin{array}{l}15 \\
(22.1)\end{array}$ & $\begin{array}{l}53 \\
(77.9)\end{array}$ & $\begin{array}{l}0 \\
(0)\end{array}$ & $\begin{array}{l}33 \\
(48.5)\end{array}$ & $\begin{array}{l}35 \\
(51.5)\end{array}$ & $\begin{array}{l}15 \\
(22.1)\end{array}$ & $\begin{array}{l}53 \\
(77.9)\end{array}$ & $\begin{array}{l}0 \\
(0)\end{array}$ & $\begin{array}{l}29 \\
(42.7)\end{array}$ & $\begin{array}{l}18 \\
(26.4)\end{array}$ & $\begin{array}{l}21 \\
130.9\end{array}$ \\
\hline \multirow[t]{2}{*}{ Bebyp } & \multirow[t]{2}{*}{$2^{\circ}$} & $\begin{array}{l}\mathrm{CHT}+ \\
\text { Bevacizumab }\end{array}$ & 92 & $\begin{array}{l}74 \\
(80.4)\end{array}$ & $\begin{array}{l}17 \\
(18.5)\end{array}$ & $\begin{array}{l}1 \\
(1.1)\end{array}$ & $\begin{array}{l}57 \\
(62)\end{array}$ & $\begin{array}{l}35 \\
(38)\end{array}$ & $\begin{array}{l}24 \\
(26.1)\end{array}$ & $\begin{array}{l}68 \\
(73.9)\end{array}$ & $\begin{array}{l}0 \\
(0)\end{array}$ & $\begin{array}{l}32 \\
(34.8)\end{array}$ & $\begin{array}{l}40 \\
(43.5)\end{array}$ & $\begin{array}{l}20 \\
(21.7)\end{array}$ \\
\hline & & $\mathrm{CHT}$ & 92 & $\begin{array}{l}74 \\
(80.4)\end{array}$ & $\begin{array}{l}16 \\
(17.4)\end{array}$ & $\begin{array}{l}2 \\
(2.2)\end{array}$ & $\begin{array}{l}75 \\
(81.5)\end{array}$ & $\begin{array}{l}17 \\
(18.5)\end{array}$ & $\begin{array}{l}24 \\
(26.1)\end{array}$ & $\begin{array}{l}68 \\
(73.9)\end{array}$ & $\begin{array}{l}0 \\
\text { (0) }\end{array}$ & $\begin{array}{l}36 \\
(39.1)\end{array}$ & $\begin{array}{l}32 \\
(34.8)\end{array}$ & $\begin{array}{l}24 \\
(26.1)\end{array}$ \\
\hline \multirow[t]{2}{*}{ VELOUR } & \multirow[t]{2}{*}{$2^{\circ}$} & $\begin{array}{l}\text { FOLFIRI + } \\
\text { Aflibercept }\end{array}$ & 187 & $\begin{array}{l}107 \\
(57.2)\end{array}$ & $\begin{array}{l}74 \\
(39.6)\end{array}$ & $\begin{array}{l}6 \\
(3.2)\end{array}$ & $\begin{array}{l}105 \\
(56.1)\end{array}$ & $\begin{array}{l}82 \\
(43.9)\end{array}$ & $\begin{array}{l}87 \\
(46.5)\end{array}$ & $\begin{array}{l}100 \\
(53.5)\end{array}$ & $\begin{array}{l}0 \\
\text { (0) }\end{array}$ & n.r. & n.r. & $\begin{array}{l}187 \\
(100)\end{array}$ \\
\hline & & $\begin{array}{l}\text { FOLFIRI + } \\
\text { Placebo }\end{array}$ & 186 & $\begin{array}{l}107 \\
(57.5)\end{array}$ & $\begin{array}{l}74 \\
(39.8)\end{array}$ & $\begin{array}{l}5 \\
(2.7)\end{array}$ & $\begin{array}{l}110 \\
(59.1)\end{array}$ & $\begin{array}{l}76 \\
(40.9)\end{array}$ & $\begin{array}{l}81 \\
(43.5)\end{array}$ & $\begin{array}{l}105 \\
(56.5)\end{array}$ & $\begin{array}{l}0 \\
\text { (0) }\end{array}$ & n.r. & n.r. & $\begin{array}{l}186 \\
(100)\end{array}$ \\
\hline \multirow[t]{2}{*}{ RAISE } & \multirow[t]{2}{*}{$2^{\circ}$} & $\begin{array}{l}\text { FOLFIRI + } \\
\text { Ramucirumab }\end{array}$ & 532 & $\begin{array}{l}263 \\
(49.5)\end{array}$ & $\begin{array}{l}268 \\
(50.3)\end{array}$ & $\begin{array}{l}1 \\
(0.2)\end{array}$ & $\begin{array}{l}289 \\
(54.3)\end{array}$ & $\begin{array}{l}243 \\
(45.7)\end{array}$ & $\begin{array}{l}171 \\
(32.1)\end{array}$ & $\begin{array}{l}361 \\
(67.9)\end{array}$ & $\begin{array}{l}0 \\
(0)\end{array}$ & $\begin{array}{l}265 \\
(49.8)\end{array}$ & $\begin{array}{l}267 \\
(50.2)\end{array}$ & $\begin{array}{l}0 \\
(0)\end{array}$ \\
\hline & & $\begin{array}{l}\text { FOLFIRI + } \\
\text { Placebo }\end{array}$ & 534 & $\begin{array}{l}259 \\
(48.5)\end{array}$ & $\begin{array}{l}273 \\
(51.1)\end{array}$ & $\begin{array}{l}2 \\
(0.4)\end{array}$ & $\begin{array}{l}326 \\
(61)\end{array}$ & $\begin{array}{l}208 \\
(39)\end{array}$ & $\begin{array}{l}158 \\
(29.6)\end{array}$ & $\begin{array}{l}376 \\
(70.4)\end{array}$ & $\begin{array}{l}0 \\
(0)\end{array}$ & $\begin{array}{l}274 \\
(51.3)\end{array}$ & $\begin{array}{l}260 \\
(48.7)\end{array}$ & $\begin{array}{l}0 \\
(0)\end{array}$ \\
\hline
\end{tabular}

ECOG: ECOG performance status; Line: line of treatment for metastatic disease; WT: wild-type; MT: mutant; n.r.: not reported; M: male; F: female; CHT: chemotherapy. Numbers in parenthesis indicate the percentage on total.

\begin{tabular}{|c|c|c|c|c|c|c|}
\hline & TML & Bebyp & RAISE & VELOUR & CORRECT & CONCUR \\
\hline Sequence Generation & Low & Low & Low & Low & Low & Low \\
\hline Allocation Concealment & Low & Low & Low & Low & Low & Low \\
\hline $\begin{array}{l}\text { Blinding of participants and } \\
\text { outcome assessors }\end{array}$ & High & High & Low & Low & Low & Low \\
\hline Selective outcome reporting & Low & Low & Low & Low & Low & Low \\
\hline Other sources of bias & Low & Unclear & Unclear & Low & Low & Low \\
\hline Overall & Low & Low & Low & Low & Low & Low \\
\hline
\end{tabular}

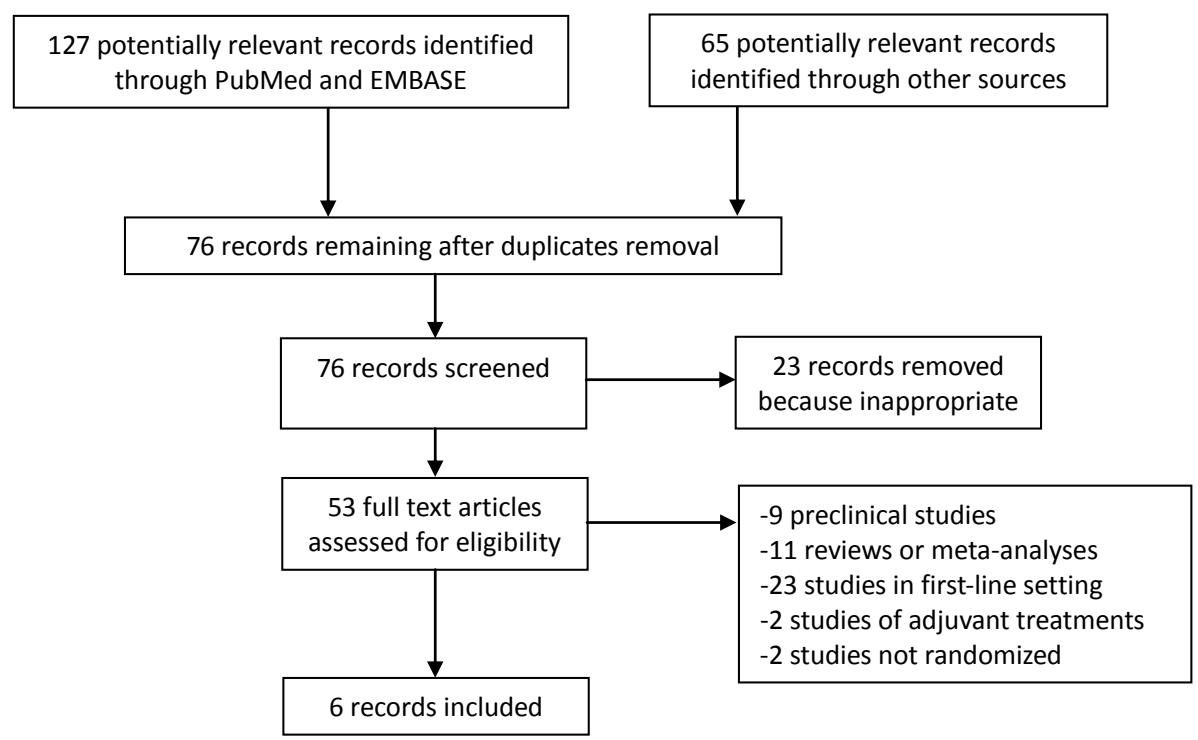

Figure 1: Trial flow chart of included studies 


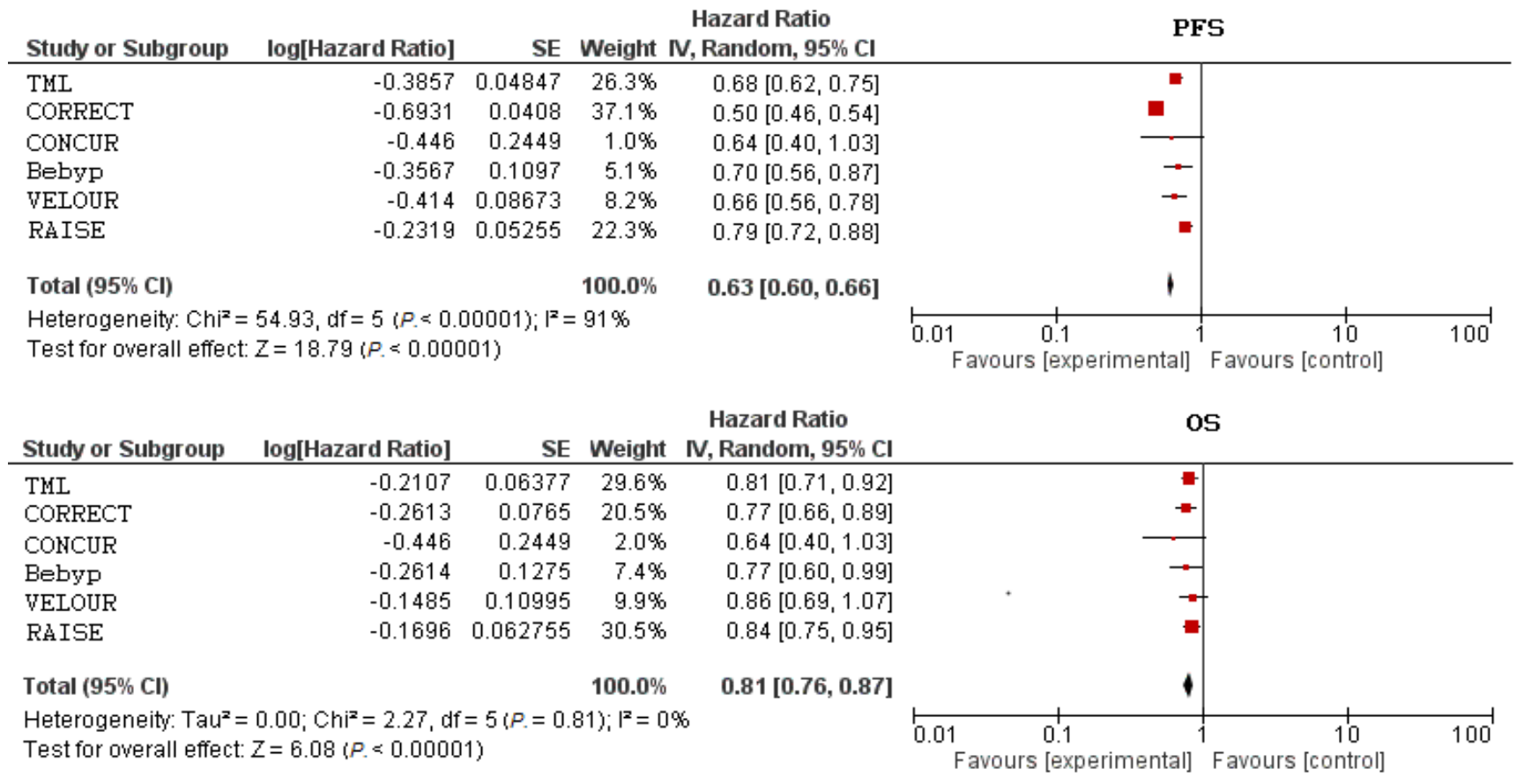

Figure 2: Progression-free survival. PFS: progression-free survival. OS: overall survival. SE: standard error.

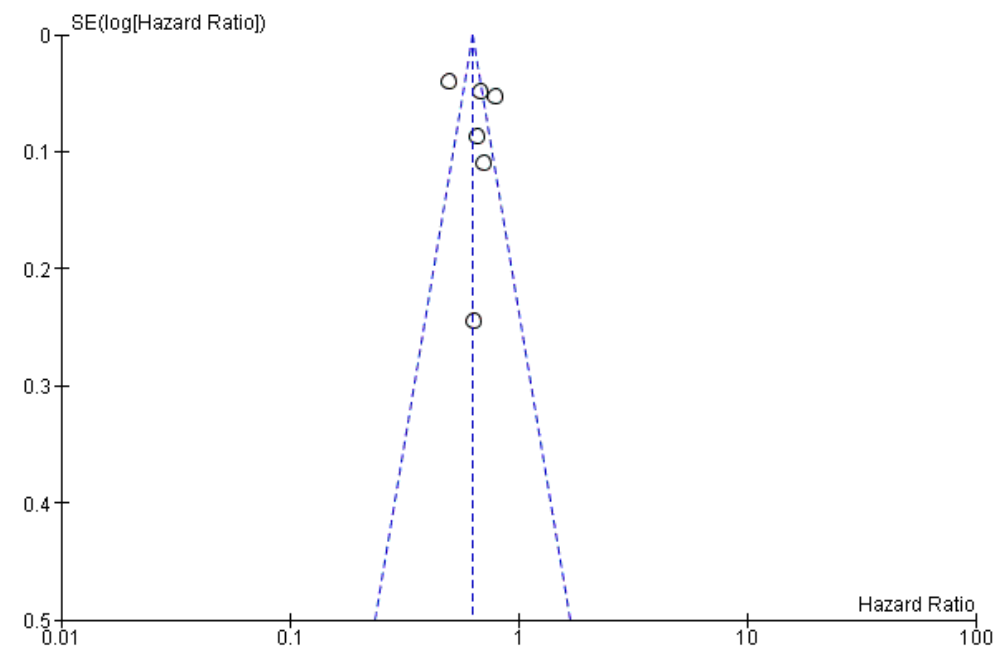

Figure 3: Small study bias and publication bias.

monoclonal antibody, was the first antiangiogenic agent approved for the treatment of colorectal cancer given its survival benefits when combined with IFL chemotherapy. ${ }^{[3]}$ Subsequent trials investigated the administration of bevacizumab in combination with different regimens of chemotherapy. ${ }^{[4,5]}$ They consistently showed benefits in progression free-survival, and many of them also reported improvements in overall survival. In recent years, other antiangiogenic drugs have been developed and tested in colorectal cancer. Aflibercept is a molecular construct that is able to bind all the different isoforms of VEGF-A, as well as other members of the VEGF family. Ramucirumab is a monoclonal antibody that targets and inactivates the VEGFR-2. Both have been investigated in two large randomized controlled trials (i.e., the VELOUR and the RAISE), in combination with FOLFIRI chemotherapy in pretreated colorectal cancer patients. Both studies were positive with almost identical results. All patients enrolled in the RAISE and a significant proportion of those in the VELOUR had received prior bevacizumab. Regorafenib is a small molecule able to block multiple targets like VEGFR-1, -2 and -3, RAF, PDGFRb and kit. It was seen 
that regorafenib helped to improve both PFS and OS in heavily pretreated patients ${ }^{[8]}$ in majority of trials; the antiangiogenic agent were suspended after progression. However, the optimal duration is unclear and there is a biological rationale to hypothesize a survival benefit from post-progression administrations. ${ }^{[10]}$ The TML and the Bebyp trials investigated protracted administration of bevacizumab after progression to a first-line chemotherapy. Both trials were positive, confirming that protracted administration of bevacizumab, beyond progression, leads to survival advantage. These trials suggest that once started, antiangiogenic agents should not be discontinued. One of the main goals of this paper is to assess if this statement is limited to bevacizumab or could conversely apply to all VEGF-targeting drugs. The analysis included all the studies which investigated the administration of anti-VEGF drugs, alone or combined with chemotherapy, in patients already progressed after a previous line of treatment including antiangiogenic agents. Our results confirmed a significant improvement of both progression free and overall survival. Most notably, the magnitude of benefit was almost identical, regardless of the drug used. All the drugs included had an exclusive activity against VEGFs or VEGFR-2, with the only exception of regorafenib. However, in the CORRECT and the CONCUR studies, a very similar amount of benefit was present and if these studies were removed, the results did not change significantly. We recognize some limitations to the present analysis. The number of studies is small, and for some molecules, only one trial was available. The time between the progression and the start of treatment were different, with some studies allowing only a very short time, unlike the Bebyp in which a longer period was allowed. Even if the results appear to be very similar, the timing of second-line antiangiogenic agents may not be negligible. Moreover, the absolute benefit in survival, although statistically significant, appears to be very small. Considering the high costs and the associated toxicities, a routine use is controversial and this strategy should be evaluated case by case, also considering patient and tumor characteristics like age, comorbidities and KRAS status. Despite these limitations, the body of evidence acquired in the last decades confirms that the inhibition of VEGF signaling can effectively improve the overall survival in metastatic colorectal cancer patients, and that a prolonged administration is associated with greater benefits. Future efforts should focus on better strategy to inhibit angiogenesis as well as preventing angiogenesis resistance. Concomitant blockage of other proangiogenic factors like FGF and PDGF could improve the effectiveness of this strategy. Many agents that can target these pathways have been developed, like sorafenib and sunitinib. Unfortunately, both failed to improve prognosis in phase III randomized trials, even if sorafenib still maintains promise for pretreated
KRAS mutant patients. ${ }^{[16-18]}$ Other antiangiogenic molecules able to target multiple pathways are under investigation. Among these, nintedanib (BIBF 1120), a multi target TKI able to efficiently block VEGFR, FGFR and PDGFR, is one of the most promising, as it has already shown to improve survival in lung adenocarcinoma. ${ }^{[19]}$ Preliminary results showed clinical activity also in colorectal cancer and results of ongoing trials are awaited in the coming years (NCT02149108, NCT02393755, NCT00904839). ${ }^{[20]}$

\section{Conflict of interest}

None declared.

\section{REFERENCES}

1. Bergers $\mathrm{G}$ and Benjamin LE. Tumorigenesis and the angiogenic switch. Nat Rev Cancer 2003; 3:401-10.

2. Carmeliet $P$ and Jain RK. Molecular mechanisms and clinical applications of angiogenesis. Nature 2011;473:298-307.

3. Hurwitz H, Fehrenbacher L, Novotny W, Cartwright T, Hainsworth J, Heim W, et al. Bevacizumab plus irinotecan, fluorouracil, and leucovorin for metastatic colorectal cancer. N Engl J Med 2004; 50:2335-42.

4. Cunningham D, Lang I, Marcuello E, Lorusso V, Ocvirk J, Shin DB, et $a l$. Bevacizumab plus capecitabine versus capecitabine alone in elderly patients with previously untreated metastatic colorectal cancer (AVEX): an open-label, randomized, phase 3 trial. Lancet Oncol 2013; 14:1077-85.

5. Giantonio BJ, Catalano PJ, Meropol NJ, O’Dwyer PJ, Mitchell EP, Alberts $\mathrm{SR}$, et al. Bevacizumab in combination with oxaliplatin, fluorouracil, and leucovorin (FOLFOX4) for previously treated metastatic colorectal cancer: results from the eastern cooperative oncology group study E3200. J Clin Oncol 2007; 25:1539-44.

6. Tabernero J, Yoshino T, Cohn AL, Obermannova R, Bodoky G, GarciaCarbonero $\mathrm{R}$, et al. Ramucirumab versus placebo in combination with second-line FOLFIRI in patients with metastatic colorectal carcinoma that progressed during or after first-line therapy with bevacizumab, oxaliplatin, and a fluoropyrimidine (RAISE): a randomised, double-blind, multicentre, phase 3 study. Lancet Oncol 2015; 16:499-508.

7. Van Cutsem E, Tabernero J, Lakomy R, Prenen H, Prausová J, Macarulla $\mathrm{T}$, et al. Addition of aflibercept to fluorouracil, leucovorin, and irinotecan improves survival in a phase III randomized trial in patients with metastatic colorectal cancer previously treated with an oxaliplatin-based regimen. J Clin Oncol 2012; 30:3499-506.

8. Grothey A, Van Cutsem E, Sobrero A, Siena S, Falcone A, Ychou M, et al. Regorafenib monotherapy for previously treated metastatic colorectal cancer (CORRECT): an international, multicentre, randomised, placebocontrolled, phase 3 trial. Lancet 2013; 381:303-12.

9. Van Beijnum JR, Nowak-Sliwinska P, Huijbers EJ, Thijssen VL, Griffioen AW. The great escape; the hallmarks of resistance to antiangiogenic therapy. Pharmacol Rev 2015; 67: 441-61.

10. Bagri A, Berry L, Gunter B, Singh M, Kasman I, Damico LA, et al. Effects of anti-VEGF treatment duration on tumor growth, tumor regrowth, and treatment efficacy. Clin Cancer Res 2010;16:3887-900.

11. Bennouna J, Sastre J, Arnold D, Österlund P, Greil R, Van Cutsem E, et al. Continuation of bevacizumab after first progression in metastatic colorectal cancer (ML18147): a randomised phase 3 trial. Lancet Oncol 2013; 14:29-37.

12. Masi G, Salvatore L, Boni L, Loupakis F, Cremolini C, Fornaro L, et al. Continuation or reintroduction of bevacizumab beyond progression to first-line therapy in metastatic colorectal cancer: final results of the randomized BEBYP trial. Ann Oncol 2015; 26:724-30. 
13. Parmar MK, Torri V, Stewart L. Extracting summary statistics to perform meta-anlyses of the published literature for survival endpoints. Stat Med $1998 ; 17: 2815-34$.

14. Higgins JP, Altman DG, Gøtzsche PC, Jüni P, Moher D, Oxman AD, et al. The Cochrane Collaboration's tool for assessing risk of bias in randomised trials. BMJ 2011;343.

15. Moher D, Liberati A, Tetzlaff J, Altman DG. Preferred reporting items for systematic reviews and meta-analyses: The PRISMA statement. PloS Med 2013; 6: e1000097

16. Carrato A, Swieboda-Sadlej A, Staszewska-Skurczynska M, Lim R, Roman L, Shparyk Y, et al. Fluorouracil, leucovorin, and irinotecan plus either sunitinib or placebo in metastatic colorectal cancer: a randomized, phase III trial. J Clin Oncol 2013; 31:1341-7.

17. Tabernero J, Garcia-Carbonero R, Cassidy J, Sobrero A, Van Cutsem E, Köhne CH, Tejpar S, et al. Sorafenib in combination with oxaliplatin, leucovorin, and fluorouracil (modified FOLFOX6) as first-line treatment of metastatic colorectal cancer: the RESPECT trial. Clin Cancer Res 2013; 19:2541-2550.
18. Samalin E, Bouché O, Thézenas S, Francois E, Adenis A, Bennouna J, et al. Sorafenib and irinotecan (NEXIRI) as second- or later-line treatment for patients with metastatic colorectal cancer and KRAS-mutated tumours: a multicentre Phase I/II trial. Br J Cancer 2014; 110:1148-54.

19. Reck M, Kaiser R, Mellemgaard A, Douillard JY, Orlov S, Krzakowski $\mathrm{M}$, et al. Docetaxel plus nintedanib versus docetaxel plus placebo in patients with previously treated non-small-cell lung cancer (LUMELung 1): a phase 3, double-blind, randomised controlled trial. Lancet Oncol 2014; 15:143-55.

20. Mross K, Büchert M, Frost A, Medinger M, Stopfer P, Studeny M, et al. Vascular effets, efficacy and safety of nintedanib in patients with advanced, refractory colorectal cancer: a prospective phase I subanalysis. BMC Cancer 2014; 14:510.

How to cite this article: Montagnani F, Di Leonardo G, Pino M, Perboni $\mathrm{S}$, Ribecco A, Fioretto L. Protracted inhibition of vascular endothelial growth factor signaling improves survival in metastatic colorectal cancer: A systematic review. J Transl Intern Med 2017; 5: 18-26. 


\section{APPENDIX}

\section{PRISMA CHECKLIST}

\begin{tabular}{ll}
\hline Section/Topic & \# Checklist Item \\
\hline TITLE & 1. Identify the report as a systematic review, meta-analysis, or both. \\
$\begin{array}{l}\text { Title } \\
\text { ABSTRACT }\end{array}$ & $\begin{array}{l}\text { 2. Provide a structured summary including, as applicable: background; objectives; data sources; } \\
\text { Structured }\end{array}$ \\
summary & $\begin{array}{l}\text { study eligibility criteria, participants, and interventions; study appraisal and synthesis methods; } \\
\text { results; limitations; conclusions and implications of key findings; systematic review registration } \\
\text { number. }\end{array}$
\end{tabular}

\section{INTRODUCTION}

Rationale

Objectives

METHODS

Protocol and

registration

Eligibility criteria

Information source

Search

Study selection

Data collection

process

Data items

Risk of bias in individual studies

Summary measures

Synthesis of results

Risk of bias across

studies

Additional analyses

RESULTS

Study selection

Study

characteristics

Risk of bias within

studies

Results of individual studies

Synthesis of results

Risk of bias across studies

Additional analysis

DISCUSSION

Summary of

evidence

Limitations

Conclusions

FUNDING

Funding
3. Describe the rationale for the review in the context of what is already known.

4 Provide an explicit statement of questions being addressed with reference to participants, interventions, comparisons, outcomes, and study design (PICOS).

5. Indicate if a review protocol exists, if and where it can be accessed (e.g., Web address), and, if available, provide registration information including registration number.

6. Specify study characteristics (e.g., PICOS, length of follow-up) and report characteristics (e.g., years considered, language, publication status) used as criteria for eligibility, giving rationale.

7. Describe all information sources (e.g., databases with dates of coverage, contact with study authors to identify additional studies) in the search and date last searched.

8. Present full electronic search strategy for at least one database, including any limits used, such that it could be repeated.

9. State the process for selecting studies (i.e., screening, eligibility, included in systematic review, and, if applicable, included in the meta-analysis).

10. Describe method of data extraction from reports (e.g., piloted forms, independently, in duplicate) and any processes for obtaining and confirming data from investigators.

11. List and define all variables for which data were sought (e.g., PICOS, funding sources) and any assumptions and simplifications made.

12. Describe methods used for assessing risk of bias of individual studies (including specification of whether this was done at the study or outcome level), and how this information is to be used in any data synthesis.

13. State the principal summary measures (e.g., risk ratio, difference in means).

14. Describe the methods of handling data and combining results of studies, if done, including measures of consistency (e.g., 12) for each meta-analysis.

15. Specify any assessment of risk of bias that may
publication bias, selective reporting within studies).

16. Describe methods of additional analyses (e.g., sensitivity or subgroup analyses, metaregression), if done, indicating which were pre-specified.

17. Give numbers of studies screened, assessed for eligibility, and included in the review, with reasons for exclusions at each stage, ideally with a flow diagram.

18. For each study, present characteristics for which data were extracted (e.g., study size, PICOS, follow-up period) and provide the citations.

19. Present data on risk of bias of each study and, if available, any outcome-level assessment (see Item 12).

20. For all outcomes considered (benefits or harms), present, for each study: (a) simple summary
data for each intervention group and (b) effect estimates and confidence intervals, ideally with a forest plot.

21. Present rest
consistency.

22. Present results of any assessment of risk of bias across studies (see Item 15).

23. Give results of additional analyses, if done (e.g., sensitivity or subgroup analyses, metaregression [see Item 16]).

24. Summarize the main findings including the strength of evidence for each main outcome; consider their relevance to key groups (e.g., health care providers, users, and policy makers). 25. Discuss limitations at study and outcome level (e.g., risk of bias), and at review level (e.g. incomplete retrieval of identified research, reporting bias).

26. Provide a general interpretation of the results in the context of other evidence, and implications for future research.

27. Describe sources of funding for the systematic review and other support (e.g., supply of data); role of funders for the systematic review.
Reported on

Title

Abstract

Background

Background

Protocol not registered

Materials and

Methods

Materials and

Methods

Materials and

Methods

Materials and

Methods

Materials and

Methods

Materials and

Methods -

Table 1

Materials and

Methods

Materials and

Methods

Materials and

Methods

Materials and

Methods

Materials and

Methods

Results- Figure

1

Results - Table

1

Not applicable

Results -

Figure 2-4

Results

Not applicable

Results

Discussion

Discussion

Discussion

Fundings 


\section{RISK OF BIAS ASSESSMENT VELOUR}

\begin{tabular}{|c|c|c|}
\hline Domain & Description & Review authors' judgement \\
\hline Sequence generation & $\begin{array}{l}\text { Permuted-block randomization, stratified } \\
\text { according to prior therapy with bevacizumab. }\end{array}$ & Low risk of bias \\
\hline Allocation concealment & $\begin{array}{l}\text { Concealment reported but not specified } \\
\text { in details. Centralized interactive voice- } \\
\text { response system. }\end{array}$ & $\begin{array}{l}\text { Centralization minimize the risk to foresee } \\
\text { the allocation. Low risk of bias }\end{array}$ \\
\hline $\begin{array}{l}\text { Blinding of participants, personnel and } \\
\text { outcome assessors }\end{array}$ & As above. No mentions of masking breaks. & Low risk of bias. \\
\hline Incomplete outcome data & $\begin{array}{l}\text { Complete reporting of primary and secondary } \\
\text { outcomes. }\end{array}$ & Low risk of bias. \\
\hline Selective outcome reporting & $\begin{array}{l}\text { No evidence of selective outcome reporting } \\
\text { in the publication. }\end{array}$ & Low risk of bias \\
\hline Other sources of bias & $\begin{array}{l}\text { No evidence of other significant sources of } \\
\text { bias. }\end{array}$ & Low risk of bias \\
\hline
\end{tabular}

\section{RAISE}

\begin{tabular}{|c|c|c|}
\hline Domain & Description & Review authors' judgement \\
\hline Sequence generation & computerized voice-response system. & Low risk of bias \\
\hline Allocation concealment & $\begin{array}{l}\text { Concealment reported but not specified } \\
\text { in details. Centralized interactive voice- } \\
\text { response system. }\end{array}$ & $\begin{array}{l}\text { Centralization minimize the risk to foresee the } \\
\text { allocation. Low risk of bias }\end{array}$ \\
\hline $\begin{array}{l}\text { Blinding of participants, personnel and } \\
\text { outcome assessors }\end{array}$ & $\begin{array}{l}\text { Double-blind, placebo-controlled. Masking } \\
\text { break allowed for emergency. No mention } \\
\text { of breaks. }\end{array}$ & Low risk of bias. \\
\hline Incomplete outcome data & $\begin{array}{l}\text { Complete reporting of primary and } \\
\text { secondary outcomes. }\end{array}$ & Low risk of bias. \\
\hline Selective outcome reporting & $\begin{array}{l}\text { No evidence of selective outcome reporting } \\
\text { in the publication. }\end{array}$ & Low risk of bias \\
\hline Other sources of bias & $\begin{array}{l}10-20 \% \text { of patients per arm discontinued } \\
\text { treatment because of patients or } \\
\text { investigator's decision. }\end{array}$ & Unclear risk of bias \\
\hline
\end{tabular}

\section{Bebyp}

\begin{tabular}{|c|c|c|}
\hline Domain & Description & Review authors' judgement \\
\hline Sequence generation & $\begin{array}{l}\text { Centralized web-based system and a } \\
\text { minimization algorithm. }\end{array}$ & Low risk of bias \\
\hline Allocation concealment & $\begin{array}{l}\text { Concealment reported but not specified } \\
\text { in details. Centralized interactive voice- } \\
\text { response system. }\end{array}$ & $\begin{array}{l}\text { Centralization minimize the risk to foresee } \\
\text { the allocation. Low risk of bias }\end{array}$ \\
\hline $\begin{array}{l}\text { Blinding of participants, personnel and } \\
\text { outcome assessors }\end{array}$ & No blinding. No placebo-control. & High risk of bias \\
\hline Incomplete outcome data & \multicolumn{2}{|c|}{$\begin{array}{l}\text { Complete reporting of primary and secondaryLow risk of bias } \\
\text { outcomes. }\end{array}$} \\
\hline Selective outcome reporting & $\begin{array}{l}\text { No evidence of selective outcome reporting } \\
\text { in the publication. }\end{array}$ & Low risk of bias \\
\hline Other sources of bias & $\begin{array}{l}\text { Trial flow chart not shown. Small difference } \\
\text { in median number of cycles in favor of } \\
\text { treatment arms ( } 9 \text { for experimental arm, } 8 \\
\text { for controls). }\end{array}$ & Unclear risk of bias \\
\hline
\end{tabular}




\section{TML}

\begin{tabular}{|c|c|c|}
\hline Domain & Description & Review authors' judgement \\
\hline Sequence generation & $\begin{array}{l}\text { Stratified permuted block design. Interactive voice-response } \\
\text { system. }\end{array}$ & Low risk of bias \\
\hline Allocation concealment & $\begin{array}{l}\text { Centralized randomization for patients included in the AIO } \\
\text { KRK 0504. Interactive voice response system for patients } \\
\text { enrolled in TML. The patient's study identification number } \\
\text { was uploaded automatically by the IVRS on the electronic } \\
\text { case-report form. }\end{array}$ & Low risk of bias \\
\hline $\begin{array}{l}\text { Blinding of participants, personnel and } \\
\text { outcome assessors }\end{array}$ & No blinding. No placebo-control. & High risk of bias. \\
\hline Incomplete outcome data & Complete reporting of primary and secondary outcomes. & Low risk of bias. \\
\hline Selective outcome reporting & $\begin{array}{l}\text { No evidence of selective outcome reporting in the } \\
\text { publication. }\end{array}$ & Low risk of bias \\
\hline Other sources of bias & No evidence of other significant sources of bias. & Low risk of bias. \\
\hline
\end{tabular}

\section{CONCUR}

\begin{tabular}{|c|c|c|}
\hline Domain & Description & Review authors' judgement \\
\hline Sequence generation & $\begin{array}{l}\text { Pre-allocated block design (block size of six) and stratified } \\
\text { randomization by number of metastatic sites (single vs } \\
\text { multiple organs) and time from diagnosis of metastatic } \\
\text { disease ( }<18 \text { months vs } \geq 18 \text { months). }\end{array}$ & Low risk of bias \\
\hline Allocation concealment & $\begin{array}{l}\text { Each bottle of study drug was labelled with a unique } \\
\text { number and assigned to patients through the IVRS. Booklet } \\
\text { labels produced by the sponsor containing appropriate label. } \\
\text { Packaging, labelling, and distribution was done centrally. }\end{array}$ & Low risk of bias \\
\hline $\begin{array}{l}\text { Blinding of participants, personnel and } \\
\text { outcome assessors }\end{array}$ & No blinding. No placebo-control. & High risk of bias. \\
\hline Incomplete outcome data & Complete reporting of primary and secondary outcomes. & Low risk of bias. \\
\hline Selective outcome reporting & $\begin{array}{l}\text { No evidence of selective outcome reporting in the } \\
\text { publication. }\end{array}$ & Low risk of bias \\
\hline Other sources of bias & No evidence of other significant sources of bias. & Low risk of bias. \\
\hline
\end{tabular}

\section{CORRECT}

\begin{tabular}{|c|c|c|}
\hline Domain & Description & Review authors' judgement \\
\hline Sequence generation & $\begin{array}{l}\text { Pre-allocated block sizes (block size six) stratified by } \\
\text { previous treatment with VEGF-targeting drugs, time from } \\
\text { diagnosis of metastatic disease ( } \geq 18 \text { months or }<18 \\
\text { months), and geographical region. }\end{array}$ & Low risk of bias \\
\hline Allocation concealment & $\begin{array}{l}\text { Study medication labelled with a unique drug pack number } \\
\text { preprinted on each bottle, assigned to the patient through } \\
\text { the interactive voice response system. }\end{array}$ & Low risk of bias \\
\hline $\begin{array}{l}\text { Blinding of participants, personnel and } \\
\text { outcome assessors }\end{array}$ & $\begin{array}{l}\text { Double blind, placebo-controlled, masked to investigators, } \\
\text { patients and sponsor. }\end{array}$ & Low risk of bias. \\
\hline Incomplete outcome data & Complete reporting of primary and secondary outcomes. & Low risk of bias. \\
\hline Selective outcome reporting & $\begin{array}{l}\text { No evidence of selective outcome reporting in the } \\
\text { publication }\end{array}$ & Low risk of bias \\
\hline Other sources of bias & No evidence of other significant sources of bias. & Low risk of bias. \\
\hline
\end{tabular}

